\title{
PSYCHOLOGY IN INDIA
}

\author{
UDAI PAREEK \\ National Institute of Basic Education, New Delhi.
}

The development of modern natural and social sciences in India can be traced back to the impact of European thought through the British system of education finally decided for this country about a hundred years back. Though India had developed its own systems of philosophy and sciences, she had later lost communication with the fast developing western world, as a result of which she was almost isolated. The British rule in the country brought in its wake a consciousness of the larger context and the realisation of the importance of modern sciences and technology. With the establishment of the first universities in India just a hundred years ago-in 1857-the study of modem sciences was securely established.

The growth and development of psychology is of still more recent origin in the country. Social sciences suffered most during the period of the Btitish rule in India. There are several reasons for this. The rulers of the country did not encourage the development of social sciences and there were no openings for those who made a mark in these sciences, as a result of which the social sciences did not attract brilliant people. This is why India has made little outstanding contribution in the field of social sciences, and particularly in psychology.

Psychology was included in philosophy courses in the Indian universities from the very beginning. It was only in 1916 that psychology was recognised as an independent subject for university courses, when Calcutta University made the beginning by starting a Department of Psychogy and by appointing late Dr. N. N. Sangupta as the first professor. Since then psychology has been steadily forging ahead as an important social science.

Though psychology is coming of age now, no exhaustive critical study of the history of the development of psychology in the country has appeared. The first valuable review of the development of psychology in the first twenty-five years of its independent existence was presented by late Dr. G. Bose (3). A recent valuable review following up the thread of Bose's review is that by Dr. S. C. Mitra, Professor of Psychology in Calcutta University, which reports the development of psychology up to the end of 1950 (8). This is one of the series on the Progress of Science in India to be undertaken by the National Institute of Sciences in India for each quinquennium. On the occassion of the Silver Jubilee of the Indian Psychological Association a brochure containing short reports of the various university departments and institutions was published (10), which also gives a glimpse of the growth of psychology in India. Another source of informtion on this subject is the report of Professor H.P. Maiti prepared for Unesco on the teaching of social psychology in India (7). Though the overall reviews are limited to the publications mentioned above, there have been published two reviews of specific fields. One is by Dr. L. Barnett who has critically surveyed the present state of testing in India (1), while the other is a sketchy account of the growth of vocational guidance in the country (4). Two more works worth mentioning in this regard are by Shri Dharma Vir who has surveyed the field of the profession of psychology with a purpose of collecting information on the careers and training opportunities available in the country (6) 
and has pointed out the need for better planning in psychology on the basis of the survey of the demand and availability of the various types of psychologists and the contribution psychology can make towards the fulfilment of the Second Five Year Plan targets of the country.

The present paper does not intend to trace the growth and history of psychology in India, nor does it report the contributions made by Indian psychologists on the different problems of psychology. A short review of the latter appears elsewhere (8) and the space alloted for the present paper does not warrant a detailed critical review. The author has tried to avoid repetition of what has already appeared in other reports and has tried in this paper to supplement them.

The growth of psychology in India has been fostered in the universities. It is only now that psychology is also growing outside the universities. Before describing briefly the present state of psychology in Indian Universities, it seems necessary that the foreign readers are acquainted with their teaching structure. After completing 10 years secondary education (which is now being raised to 11 years) a student is entired to opt for higher education and prepare for a 2-year course (which is known as Intermediate and which is proposed to be abolished now). This course is intended to prepare the student for the course of the first university degree (Bachelor). The duration of the course for the Bachelor's degree is of two years (which is now proposed to be raised to three years consequent upon the abolition of the Intermediate stage). The first degree can be followed by next degree (Master) after completing a further 2 years' course. This is, in a way, the last degree of the University. A student has to study 3 or 4 subjects at the graduate (Bachelor) level and only one subject at the post-graduate (Master) level. Any student may take up a topic for research and do work at least for two years (but in practice it is often more) to qualify for Doctorate. We have a total number of 33 universities in India of which one university is an engineering university and the rest have provision of teaching all subjects. Two universities are of federative character, into a teaching organisation constituent colleges located in one town; some are of unitary residential character where teaching in different faculties is organiszed in the universities; while others are teaching-cum-affiliating combining reliance on outside colleges for examinations with teaching departments of their own; and only one is purely affliating in character having no teaching department of its own.

Psychology is taught almost in all the universities in India, except one engineering university, as a part of courses of philosophy, sociology, social work or education. Psychology has been included as a paper in philosophy courses. From the point of view of courses the branch of psychology most widely taught, after general psychology, is educational psychology. This is followed by social psychology in which the total number of courses offered by the various universities in different subjects and at different stages is 62 (7, p. 197). Fifteen universities have provision for teaching of psychology as an independent subject at the graduate, honours or post-graduate level.

Calcutta University was the first to start courses in psychology (in 1916) and was followed by Mysore University where the department of psychology was established in 1924 with Dr. N. V. Gopalawswamy as the head. Then a laboratory was organised at Lucknow University by Dr. Sengupta who left Calcutte to join Lucknow in 1929. This in as followed suit by the Panjab University, Muslim University Aligarh, Hindu Univert.y Banaras, Madras University, Patna University etc. Most of these universities have 
good laboratories: A seperate course in M. A. in psychology contemplated to be started in Delhi University from the beginning of the next academic year.

There are some important institutions also which are doing significant work in psychology. Some of these have university affliacions, while the others are service and research organisations having no relationship with universities.

The most important organisation from this point of view is the Psychological Research Wing of the Defence Ministry, Govt. of India, New Delhi. Dr. Sohan Lal is in charge of this organisation which has been doing valuable work.

Professor Maiti organised the Institute of Psychological Research and Service at Patna, at which post-graduate courses in applied psychology were started.

Some of the orher organisations where significant work in psychology is being done are All-India Institute of Mental Health Benglore; Department of Anthoropology, Indian Museum, Calcutta; Indian Institute of Science, Banglore; Tata Institute of Social Sciences, Bombay; Bureau of Psychology, Allahabad; B. M. Institute of Child Development, Ahmedabad; Ahmedabad Textile Industries Research Association, Ahmedaban.

Great fillip has been given to the advancement of psychology in the country by the starting of some new organisations. A Psychometric unit has been created at the Indian Statistical Institute, Calcutta. A Centre for research in the social implications of industrialisation and technological progress has recently been set up by Unesco at Calcutta, where important work in social psychology is anticipated. A psychological unit has also been recently attached with the Directorate General of Ordinance, Ministry of Defence. The Labour Ministry of the Govt. of India has started a vocational guidance unit for Employment Exchange with Dr. H. P. Mehta in Charge. A private organisation Manasayan has started working as a centre for distributing foreign tests in India, publishing Indian tests and organising research in testing.

Mention may also be made in this connection of the growing number of vocational and educational guidance bureaus in the country. The central Bureau of Educational and Vocational Guidance was started by the Union Ministry of Education about two years back. The number of guidance bureaus is steadily growing in the country. In addition to some university departments of psychology, which have provision of guidance services, independent bureaus have started working. State Governments of Bombay and Unttar Pradesh were pioneers in this respect. Since 1953 when the first seminar of guidance workers was organised, the guidance movement has gatheren momentum. Guidance bureaus are being started by many private organisations also. The practice of having psychologists has also made its beginning in some progressive schools.

Psychology as a profession is still to find its secure place in India. The greatest demand in the country is for teaching personnel. The present position as shown by Shri Dharma Vir (5) is not encouraging. The following table based on the table given by him gives some idea about the professional position of psychology. The figures of the demand are based on the analysis of one years advertisement which appeared in a widely read daily Statesman, while the figures of availablity are based on the analysis of the Directory of Indian Psychologists 1957 (9).

The demand for the various categories of psychologists is, however, steadily growing. The problems of professoin have already made themselves felt and this topic has demanded serious attention in the gathering of psychologists (2). 
Table 1. Percentage of Psychologists Engaged and Demanded.

\begin{tabular}{|c|c|c|c|}
\hline & \multirow{2}{*}{ Types of Psychologists } & \multicolumn{2}{|c|}{ Percentage } \\
\hline & & Engaged & Demanded \\
\hline 1. & Psychologists, College Teaching & 51.3 & 23.0 \\
\hline 2. & Educational Research & 4.2 & 15.4 \\
\hline 3. & Vocational Councellors & 5.5 & 13.2 \\
\hline 4. & Psychologists, State Civil Service & 5.0 & 12.2 \\
\hline 5. & Director of Psychology, State Agency & 5.5 & 5.1 \\
\hline 6. & Personnel Examiner & .85 & 5.1 \\
\hline 7. & Personnel Technical, Industry & - & 2.6 \\
\hline 8. & Psychologist, Juvevile Correctional Institute & .42 & - \\
\hline 9. & Consulting Psychologist & 4.2 & 5.1 \\
\hline 10. & Research Psychologist, General & 12.7 & 7.7 \\
\hline 11. & Paychometrist & 2.5 & - \\
\hline 12. & Psychologist, Clinical & 1.3 & - \\
\hline 13. & Psychologists, Child Guidance Clinic & 2.9 & 7.7 \\
\hline 14. & Psychologists for Mental Hespitals & 2.5 & 2.6 \\
\hline 15. & Sexologists & .85 & - \\
\hline 16. & Social Worker & .42 & - \\
\hline
\end{tabular}

There is an all-India organisation known as "Indian Psychological Association" with the head office at Calcutta. It was found in 1927. Though the association is not as active as sister organisations in other countries, it has been able to inspire a professional feeling among the psychological workers in the various parts of the country. Till recently it had unitary character, enrolling members from the various parts of the country. A change was made last year with the opening of a branch of the IPA at Delhi under the chairmanship of Dr. N. V. Banerjee, University Professor of Philosophy and Psychology. The constitution of IPA is under discussion and it is hoped that it will adopt federative character. Besides this national association, there are local and regional associations also working in the different states. Some useful gathering of these associations are being held from time to time.

There is no seperate annual gathering of psychologists of the country. There has developed the practice for psychologists to meet during the annual session of the Indian Sciences Congress Association. The Section of Psychology in Indian Science Congress Association, was created in 1927, the year of the foundation of Indian Psychological Association. Since then papers are read by psychologists at the sectional meetings of ISCA, and the abstracts of the papers are published in the proceedings of ISCA. Annual meeting of Indian Psychological Association is also held at this time.

Another national professional association is the Indian Psycho-Analytical Society started in 1922 in Calcutta. Late Dr. G. Bose who was celebrated psychoanalyst was mainly responsible for the activities of the society.

During recent years the problem of organising the profession of psychology has mode itself felt. Some discussions on this topic were held during the 1954 session of Indian Science Congress Association and the idea of compiling a Directory of Indian Psychologists was then mooted. Dr. Raj Narain compiled and distributed memeographed copies of the Directory at the 1955 session. The first printed edition of the Directory was, however, issued by Manasayan in 1957 (9). It is hoped that the next edition in 
1958 will bring the entries up-to-date.

The professional journals published in a country also indicate the development of the profession. The number of journals devoted to technical papers on psychological subjects has considerably increased during recent years. Unfortunately no significant journals devoted exclusively to psychological research and discussions are published in Indian languages. Now as Indian languages are attaining importance and are in the process of being recognised as media of higher education, it is hoped that journals in these languages will also start publication.

The oldest journal is the Indian Journal of Psychology, the organ of Indian Psychological Association. It is a quarterly and publishes research papers. The Indian Psychoanalytical society also publish a quarterly entitled Samiksa. Another journal started some years back is Journal of Education \& Psychology published by Faculty of Education and Psychology, M. S. University, Baroda. Journal of Educational \& Vocational Guidance is the organ of All-India Educational \& Vocational Guidance Association.

Some journals started publication but were discontinued mostly for want of finances. Indian Journal of Educational Research was published from Bombay for many years. Indian Journal of Psychiatry was published from Ranchi for some time. A journal entitled Psy. chology and Society was edited by late Prof. Paras Ram from Delhi.

Most of the research journals devoted to education or sociology also carry papers on psychological topics. Mention may be made among such journals of Indian Journal of Social $W$ ork published by Tata Institute of Social Sciences, Bombay. Uttar Pradesh Govt. publishes a quarterly Shiksha which is bilingual in character carrying articles in Hindi and English. Another research quarterly, also bilingual in character, Education \& Psychology, is published from Delhi, of which the author also shares editorial responsibility.

Recently some more research journals have started publication. Mention may be made of Manasi an occasional bulletin from Lucknow University and Psychological Studies from Mysore. University research journals also publish papers devoted to psychological research. Psychological researches also find place in organs of some of the research of higher institutions. Abstracts of the papers read can be found in the annual proceedings of Indian Science Congress Association.

Though Psychology is a young science and is struggling its way to secure professional status, the rapid development of the country has opened possibilities for the development of Psychology in India.

\section{REFERENCES}

1. Barnett, L. Surves of research with psychological tests in India. Psychol. Bull. 1955, 42, $106-112$.

2. Bhatt, L. J. Psychology as a profession. Presidential address of the Section of Fsychology and Educational Sciences, Agra 1956.

3. Bose, G. Progress of psychology in India during the past twenty-five years. Calcutta, Indian Science Congress Association, 1938.

4. Chothina, F. S., \& Mahta, H. P. A brief account of vocational guidance movement in India J. Voc Edu Guide 1955, 2, 107-109.

5. Dharma Vir. Planning in psychology in India. Educ. \& Psychol., 1957, 4, 1-16.

6. Dharma Vir. Careers in psychology in India to be publisbed by Manasayan, Delhi. 6.

7. Maiti, H. P. "Special report on the teaching of social psychology". in the Teaching of the Social Sciences in India, 1956 Paris, Unesco.

8. Mitra, S. C. Progress of psychology in India. Ind. J. Psychol., 1955, 30, 1-21.

9. Raj Narain, \& Udai Pareek (Eds). Directory of Indian Psychologists. 1957 Delhi, Manasayan.

10. Twenty-five years of India Psychological Association. Calcutta, Indian Psychological Association 1950. 